\title{
The Complete Chloroplast Genome Sequence of Viburnum odoratissimum and Phylogenetic Relationship with Other Close Species in the Adoxaceae Family
}

\author{
Le Thi Yen, Joonho Park ${ }^{*}$ \\ Department of Fine Chemistry, Seoul National University of Science and Technology, Seoul, South Korea
}

Email address:

Jhpark21@seoultech.ac.kr (J. Park)

${ }^{*}$ Corresponding author

\section{To cite this article:}

Le Thi Yen, Joonho Park. The Complete Chloroplast Genome Sequence of Viburnum odoratissimum and Phylogenetic Relationship with Other Close Species in the Adoxaceae Family. Plant. Vol. 9, No. 2, 2021, pp. 28-35. doi: 10.11648/j.plant.20210902.12

Received: April 5, 2021; Accepted: April 27, 2021; Published: May 8, 2021

\begin{abstract}
The chloroplast genome structure and gene content are highly conserved among land plants, providing valuable information for the studies of taxonomy and plant evolution. Viburnum odoratissimum is a well-known evergreen shrub widely distributed in Asia. It possesses excellent medicinal properties used as traditional medicine for menstrual, stomach, and kidney cramps. In this study, the complete chloroplast genome (cpDNA) of $V$. odoratissimum is reported and compared with five close Viburnum species and an outgroup. The cpDNA of $V$. odoratissimum is $158,744 \mathrm{bp}$ in length and contains 130 genes with 17 genes duplicated in the inverted repeat region. The gene content, gene organization and GC content in $\mathrm{V}$. odoratissimum are highly similar to other Viburnum species. A total of 270 tandem repeats is found in these plastomes, most of which are distributed in intergenic space. Differences in the location of the IR/SC boundaries reflect expansions and contractions of IR regions in all species studied. Phylogenetic analysis based on complete chloroplast genomes and the combination of barcodes indicates a sister relationship between V. odoratissimum and V. brachybotryum. Furthermore, a comparative cpDNA analysis identifies three DNA regions (trnC-petN-psbM, trnH-psbA, ndhC-trnV) containing high divergence among seven studied species that could be used as potential phylogenetic markers in taxonomic studies.
\end{abstract}

Keywords: Adoxaceae, Barcodes, Phylogenetic Relationship, Viburnum odoratissimum

\section{Introduction}

The genus Viburnum comprise about 200 species of deciduous shrubs, evergreen and small trees, which are broadly distributed in subtropical and temperate Northern Hemisphere and spread across the mountain regions of South Asia and South America, Mexico, and Columbia [1, 2]. Viburnum together with Sambucus and Adoxa were members of Caprifoliaceae but was recently moved to the new group, Adoxaceae, according to phylogenetic analyses [3]. Most Viburnum species have become popular ornamental plants because of their eye-catching flowers with a light fragrance and berries. Moreover, many species in the genus Viburnum have utilized as the traditional folk in China, Russia and Ukraine for a number of diseases, such as menstruation, hypertension, flu, tuberculosis, renal infection, stomach ache, duodenal ulcers [4-6]. These species possessed a considerable number of secondary metabolites: monoterpenes, sesquiterpenes, diterpenes [6], diterpenoids, triterpenoids, iridoids [7, 8], chlorogenic [5], amyrin, lupeol [4], resulting in many biological properties, including antiinflammatory, antibacterial, antioxidant, antitussive activities $[5,9,10]$.

The phylogenetic relationship within the genus Viburnum has been extensively elucidated using not only morphological characters [11] but also nuclear DNA regions, such as the nuclear ribosomal internal transcribed spacer (ITS), the granule-bound starch synthase gene (GBSSI) [1, 12]. Recently, the chloroplast nucleotide sequences are highly supportive in deciphering the phylogenetic relationship among Viburnum genus using trnK, matK, $r b c L$, psbA-trnH, rpl32-trnL [1, 13, 14]. However, molecular phylogenetic studies based on several chloroplast markers remain a number of issues that can cause misleading evaluation of the 
relationship [15]. Complete chloroplast genomes have been widely used in phylogeny reconstruction to overcome this problem because it provides valuable information on plant evolution, and a rich source of data to estimate of phylogenetic relationships [16].

In this study, we report the complete nucleotide sequence of Viburnum odoratissimum, along with a comparative analysis with other species in the genus Viburnum. The comparison with other published chloroplast genomes in related families is performed to expand understanding of the plastid genome diversity of Viburnum species. Furthermore, some new DNA barcodes containing high nucleotide divergence are identified. These hotspots could be considered as potential molecular markers for phylogenetic tree reconstruction within the Viburnum genus.

\section{Materials and Methods}

\subsection{Sampling and Sequencing}

The sample of $V$. odoratissimum was collected from National Institute of Biological Resources, Incheon, Korea (NIBRGR0000081148).

Approximately $5 \mathrm{~g}$ of the leaves was used for isolation total genomic DNA following a modified CTAB method [17] with a minor modification. The quality of the extracted DNA was assessed by using spectrophotometry and electrophoresis on $1 \%(\mathrm{w} / \mathrm{v})$ agarose gel. A total of $10 \mu \mathrm{g}$ purified genomic DNA was utilized to sequence the chloroplast genome using PacBio RS II system. The quality of the raw data was assessed to remove low-quality reads. The published complete chloroplast genome of $V$. erosum (MN641480.1) was downloaded from NCBI for a comparison.

\subsection{Chloroplast Genome Assembly and Annotation}

The filtered subreads were mapped to the reference genome using BWA Aligner [18]. The matched subreads were selected for the de novo assembly with CANU version 1.8 [19]. All contigs were checked overlapped region using nucmer and mummerplot. Annotation and visualization for the assembled chloroplast genome were performed with an Annotation tool - GeSeq [20]. Finally, the circular gene map was drawn with OGDraw version 1.3.1 [21]. The complete chloroplast genome of $\mathrm{V}$. odoratissimum was deposited in GenBank with accession number MN836381.

\subsection{Sequence Analysis}

Six chloroplast genome sequences, Viburnum utile (KX792264), Viburnum betulifolium (MG738665), Viburnum japonicum (MH036593), Viburnum erosum (MN218778), Viburnum brachybotryum (MN524624) and Tetradoxa omeiensis (NC_034793), were obtained from NCBI for a comparison.

Tandem Repeat Finder version 4.09 [22] was used to search tandem repeats. Additionally, simple sequence repeats (SSRs) were detected by MISA [23] with the following settings for numbers of repetitions: 10 for mono-, 6 for di-, 5 for all tri-, tetra-, penta-, and hexanucleotide.

The seven complete chloroplast genomes were aligned and visualized with the online comparison tool mVISTA [24] using $V$. odoratissimum as a reference. To analyze nucleotide variability, seven studied chloroplast genome were aligned using ClustalX 1.81 [25] and then conducted a sliding window analysis using DnaSP version 6.10.03 [26].

\section{Results and Discussion}

\subsection{Characteristics of Viburnum Odoratissimum Chloroplast Genome}

The complete cpDNA of $V$. odoratissimum is $158,744 \mathrm{bp}$ in size, with a pair of inverted repeat regions (IRs) of 26,494 bp that separate a large single-copy (LSC) region of 87,348 bp from a small single-copy (SSC) region of 18,267 bp (Figure 1). The total GC content is $38.1 \%$, with the highest content in IR regions (43\%), followed by an LSC (36.4\%), and an SSC accounting for $32.1 \%$. All the sequences of protein-coding genes and tRNA genes in the $V$. odoratissimum cp genome are encoded by 26,278 codons. Leucine is the most frequent amino acid with $10.5 \%$ (2768) of the codon and cysteine is the least frequent with $1.1 \%(294)$.

The $V$. odoratissimum cp genome encodes 129 genes, consisting of 84 protein-coding genes, 37 tRNA genes, and eight rRNA genes. Among these genes, 17 genes are duplicated in IR regions, six functional genes, seven tRNA genes, and four RNA genes. In total, there are 22 introncontaining genes, 19 of which contain one intron, and three of which contain two introns (clpP, rps 12, and $y c f 3)$. The largest intron is largest in trnK-UUU which itself contains the matK gene.

\subsection{Comparative Complete Chloroplast Genomic Analysis}

\subsubsection{Genome Structure and Content}

The complete chloroplast genome of $V$. odoratissimum (MN836381) is compared to those of five others in Viburnum: Viburnum utile (KX792264), Viburnum betulifolium (MG738665), Viburnum japonicum (MH036493), Viburnum erosum (MN218778), Viburnum brachybotryum (MN524624), and an outgroup, Tetradoxa omeiensis (NC_034793). Each chloroplast genome encodes for a total of 130 genes, including 85 protein-coding genes, 37 tRNA genes, and eight rRNA genes. There are 17 genes duplicated in the IR regions. A total of 22 genes contains introns, 19 of which contains one intron while three genes have two introns (clpP, rps12, and ycf3).

The cpDNA size of $V$. odoratissimum is the largest among seven studied genomes (158,744 bp), which is larger than the smallest cp genome of $V$. brachybotryum by $1,311 \mathrm{bp}$ (Table 1). There are slight differences in length between IR $(26,123$ $26,517 \mathrm{bp})$ or SSC $(18,338-18,795 \mathrm{bp})$, and the main reason for the variation in genomic size is a difference in the length of the LSC (86,526-87,348 bp). 


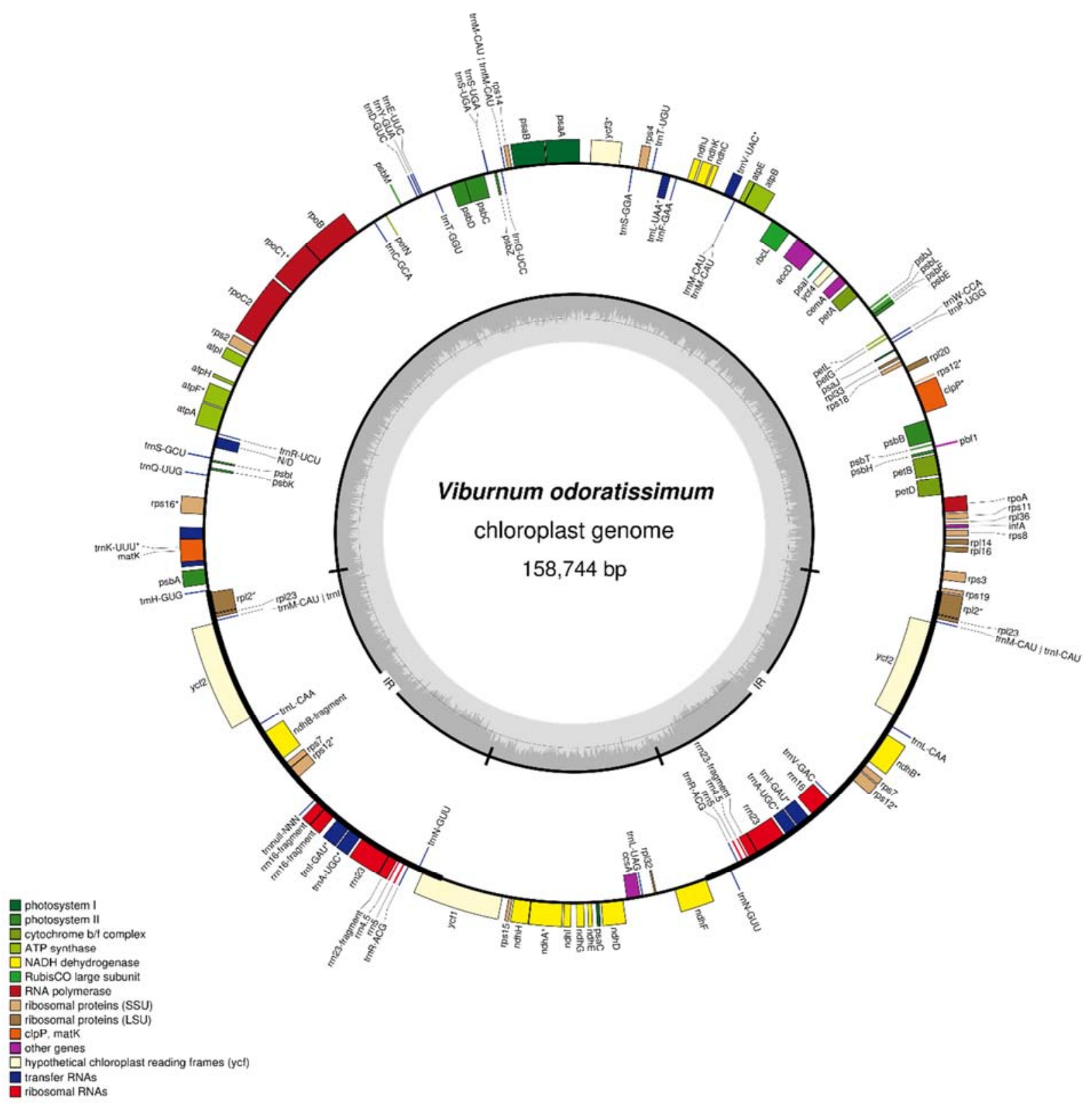

Figure 1. Gene map of V. odoratissimum chloroplast genome. Genes drawn inside and outside the circle are transcribed anti-clockwise and clockwise, respectively. Genes are differently colored by the functional groups which genes are affiliated with.

Table 1. Summary of complete chloroplast genomes of six Viburnum species and an outgroup.

\begin{tabular}{|c|c|c|c|c|c|c|c|}
\hline Features & $\begin{array}{l}\text { Viburnum } \\
\text { odoratissimum }\end{array}$ & $\begin{array}{l}\text { Viburnum } \\
\text { utile }\end{array}$ & $\begin{array}{l}\text { Viburnum } \\
\text { betulifolium }\end{array}$ & $\begin{array}{l}\text { Viburnum } \\
\text { japonicum }\end{array}$ & $\begin{array}{l}\text { Viburnum } \\
\text { erosum }\end{array}$ & Viburnum brachybotryum & $\begin{array}{l}\text { Tetradoxa } \\
\text { omeiensis }\end{array}$ \\
\hline Genome size & 158,744 & 157,620 & 158,023 & 158,614 & 158,624 & 157,433 & 157,502 \\
\hline LSC Length & 87,348 & 86,576 & 86,761 & 87,060 & 87,060 & 86,552 & 86,526 \\
\hline SSC Length & 18,408 & 18,726 & 18,338 & 18,523 & 18,530 & 18,615 & 18,682 \\
\hline IR length & 26,494 & 26,159 & 26,462 & 26,516 & 26,517 & 26,133 & 26,147 \\
\hline Coding Size & 78,834 & 75,411 & 77,061 & 78,852 & 77,124 & 47,316 & 75,525 \\
\hline GC content $(\%)$ & 38.1 & 38.1 & 38.1 & 38.1 & 38.1 & 38.1 & 37.7 \\
\hline Total number of genes & 130 & 130 & 130 & 130 & 130 & 130 & 130 \\
\hline Protein-coding genes & 85 & 85 & 85 & 85 & 85 & 85 & 85 \\
\hline Duplicated genes & 17 & 17 & 17 & 17 & 17 & 17 & 17 \\
\hline tRNA genes & 37 & 37 & 37 & 37 & 37 & 37 & 37 \\
\hline rRNA genes & 8 & 8 & 8 & 8 & 8 & 8 & 8 \\
\hline Genes with introns & 22 & 22 & 22 & 22 & 22 & 22 & 22 \\
\hline Pseudogenes & & & & & & $\begin{array}{l}n d h B, \quad m a t K, \quad r p o B, \quad n d h J, \quad r p o A \text {, } \\
r p l 16, y c f 2, n d h H, r p s 15 \text {, and } y c f 1\end{array}$ & \\
\hline
\end{tabular}


Table 2. Simple sequence repeat analysis in the seven studied species.

\begin{tabular}{|c|c|c|c|c|c|c|c|c|c|}
\hline $\begin{array}{l}\text { SSR } \\
\text { Type }\end{array}$ & Repeat unit & $\begin{array}{l}\text { Viburnum } \\
\text { odoratissimum }\end{array}$ & $\begin{array}{l}\text { Viburnum } \\
\text { utile }\end{array}$ & $\begin{array}{l}\text { Viburnum } \\
\text { betulifolium }\end{array}$ & $\begin{array}{l}\text { Viburnum } \\
\text { japonicum }\end{array}$ & $\begin{array}{l}\text { Viburnum } \\
\text { erosum }\end{array}$ & $\begin{array}{l}\text { Viburnum } \\
\text { brachybotryum }\end{array}$ & $\begin{array}{l}\text { Tetradoxa } \\
\text { omeiensis }\end{array}$ & Total \\
\hline \multirow{2}{*}{ Mono } & $\mathrm{A} / \mathrm{T}$ & 39 & 38 & 38 & 36 & 35 & 43 & 45 & 274 \\
\hline & $\mathrm{C} / \mathrm{G}$ & 2 & 1 & 0 & 1 & 1 & 0 & 1 & 6 \\
\hline Di & AT/AT & 1 & 2 & 1 & 1 & 2 & 1 & 4 & 12 \\
\hline Tri & AAT/ATT & 0 & 1 & 1 & 1 & 1 & 0 & 0 & 4 \\
\hline Total & & 42 & 42 & 40 & 39 & 39 & 44 & 50 & 296 \\
\hline
\end{tabular}

The cpDNA of six Viburnum species has the same overall GC contents $(38.1 \%)$ which is higher than that of $T$. omeiensis $(37.7 \%)$. The coding size of $V$. odoratissimum $(78,834 \mathrm{bp})$ is the second-largest genome among these complete cp genomes, while the smallest is from $V$. brachybotryum with the size of 47,316 bp. The reason for a significant difference in protein-coding size is a presence of 10 pseudogenes in $V$. brachybotryum, including $n d h B$, matK, $r p o B, n d h J, r p o A, r p l 16, y c f 2, n d h H, r p s 15$, and $y c f 1$. The abundance of pseudogenes in $V$. brachybotryum have few nucleotides that differ from these genes in other Viburnum species, that could be resulted from genomic mutations or sequencing errors [27].

\subsubsection{Repeat Structure}

In these studied chloroplast genomes, a total of 270 tandem repeat sequences is identified, with each accession containing 31-47 repeats (Figure 2A). The length of repeated sequences ranges mainly from $31-50 \mathrm{bp}$, consistent with reports in other angiosperms [28]. These repeats are primarily distributed in the intergenic spaces, but a few are located in the coding region ( $r p o C 1, r p s 18, y c f 2, y c f 1, p s a A)$, intron $(c l p P)$. In terms of quadripartite structure, tandem repeat equally distributed in the LSC and IR regions, accounting for around $42 \%$ each, while the SSC region has only $16.3 \%$.

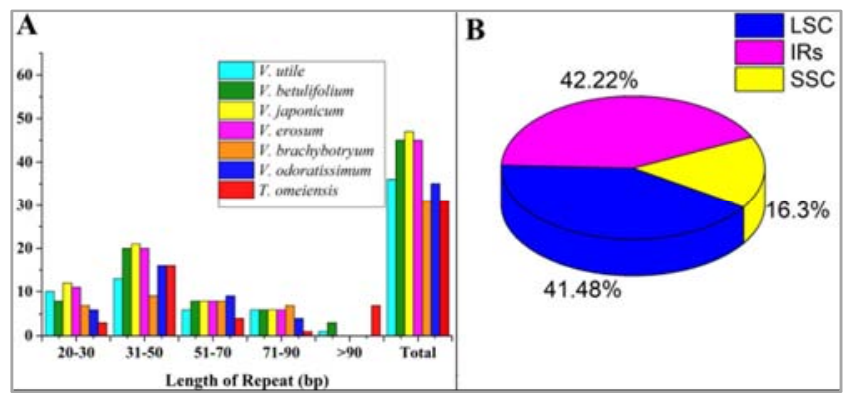

Figure 2. Length and distribution of tandem repeats.

Simple sequence repeats (SSRs) are repeating short DNA motifs of 1-6 nucleotides that are excellent molecular markers in plant genetics and polymorphism researche [29]. Herein, the types and quantity of SSRs are analyzed using MISA software. We found a total of 296 SSRs in the seven studied species, with each accession containing 39-50 SSRs. Most of these SSRs are distributed in the single-copy regions. Mononucleotide is the most frequent repeat, accounting for approximately $94.6 \%$ of all SSRs, followed by dinucleotide $(4.0 \%)$ and trinucleotide $(1.4 \%)$. A total of 274 mononucleotide repeats $(97.9 \%)$ is $\mathrm{A} / \mathrm{T}$ repeat, and all di- and tri- nucleotide repeats are AT/AT repeat and AAT/ATT repeat, respectively.

\subsubsection{Ir Contraction and Expansion}

The shrinkage and expansion of the IR/SC boundary regions of seven studied species are presented in Figure 3. The rps 19 gene, located in the LSC region, extends into the IRb region by 245 bp - 247 bp in all Viburnum species, while the distance from rps19 gene to the border is $97 \mathrm{bp}$ in $T$. omeiensis. The IRb/SSC boundary region is highly similar between these species. Briefly, the $\operatorname{trn} N$ gene and $n d h F$ gene are located on either side of this boundary, separated by $1,372 \mathrm{bp}$ ( $V$. brachybotryum) to $1,977 \mathrm{bp}$ ( . japonicum $)$. The $y c f 1$ gene spans to the regions at the junction of the SSC/IRa region in all seven species with 4,273 bp ( $V$. betulifolium) to $4,733 \mathrm{bp}$ ( $T$. omeiensis) located in the SSC region. The IRa/LSC boundary is quite conserved between Viburnum species. The $\operatorname{trn} H$ gene is located in the LSC region and it is 0-80 bp apart from the IR/LSC junction in Viburnum, and $330 \mathrm{bp}$ in Tetradoxa omeiensis.

\subsubsection{Divergence Hotspot Regions}

To determine the divergent regions that could be applied to the phylogenetic study, the seven chloroplast genomes were aligned with mVISTA (Figure 4). The comparison shows that the IR regions are less divergent than the single-copy regions and the non-coding regions contain more hypervariable regions than the coding regions. The significant difference between these species includes trnH-psaA, atpH-atpI, trnCpetN-psbM, rbcL-accD, psbE-petL and ndhF-rpl32-trnL.

The nucleotide variability values in all seven accessions were detected with DnaSP software to quantify the diversity at the sequence level (Figure 5). The Pi value ranges from 0 to 0.277 , indicating a partial difference among these plastomes. As expected, the LSC and the SSC regions are higher divergences than the IR regions. The region $\operatorname{trn} C$ pet $N$-psbM is the most divergent region with a $\mathrm{Pi}$ value of 0.277 . We also detect some regions that differ among seven studied species, including intergenic spacers trnH-psbA, $n d h C$-trnV, trnE-trnT, ndhF-rpl32-trnL and coding regions rpl16 and rpl22. These regions with a high degree of nucleotide variation could be used as potential molecular markers to reconstruct a phylogenetic tree in the Viburnum genus. Choi et al. used the regions of $\operatorname{trnK}$, matK, and $r b c L$ to distinguish Viburnum species [13] but our study shows that these sequences in the Viburnum chloroplast genomes exhibit low divergence. 


\begin{tabular}{|c|c|c|c|c|c|c|c|c|}
\hline \multirow[b]{3}{*}{ V. odoratissimum } & \multicolumn{2}{|c|}{247 bp 32 bp } & \multirow{2}{*}{$\mid \begin{array}{l}1723 \mathrm{bp} \\
\mathrm{trnN}\end{array}$} & \multirow{2}{*}{$\frac{36 \mathrm{bp}}{n d h F}$} & \multirow{2}{*}{\multicolumn{2}{|c|}{$\begin{array}{l}4301 \mathrm{bp} 1396 \mathrm{bp} \\
y c f 1\end{array}$}} & \multirow{2}{*}{\multicolumn{2}{|c|}{$16 \mathrm{bp}, t r n H$}} \\
\hline & \multicolumn{2}{|c|}{ rps19 } & & & & & & \\
\hline & LSC & $\mathrm{IRb}$ & 26,494 & SSC & 18,408 & IRa & 26,494 & LSC \\
\hline & \multicolumn{2}{|c|}{$247 \mathrm{bp} 32 \mathrm{bp}$} & $1385 \mathrm{bp}$ & $118 \mathrm{bp}$ & \multirow{2}{*}{$\begin{array}{c}4588 \mathrm{bp} \\
y c f 1\end{array}$} & \multirow[t]{2}{*}{$1061 \mathrm{bp}$} & $3 \mathrm{bp}$ & $\operatorname{trnH}$ \\
\hline & rpsig & $r p l 2$ & $\operatorname{trnN}$ & $n d h F$ & & & $r p l 2$ & \\
\hline \multirow[t]{3}{*}{ V. utile } & LSC & IRb & 26,159 & SSC & 18,726 & IRa & 26,159 & LSC \\
\hline & \multicolumn{2}{|c|}{$247 \mathrm{bp} 32 \mathrm{bp}$} & $1709 \mathrm{bp}$ & $32 \mathrm{bp}$ & \multirow{2}{*}{\multicolumn{2}{|c|}{$\begin{array}{l}4273 \mathrm{bp} 1382 \mathrm{bp} \\
y c f 1\end{array}$}} & $3 \mathrm{bp}$. & $\operatorname{trnH}$ \\
\hline & \multicolumn{2}{|l|}{ rps19 } & $\operatorname{trnN}$ & $n d h F$ & & & $r p l 2$ & \\
\hline \multirow[t]{3}{*}{ V. betulifolium } & LSC & $\mathrm{IRb}$ & 26,462 & SSC & 18,338 & IRa & 26,462 & LSC \\
\hline & \multirow{2}{*}{$\begin{array}{r}245 \mathrm{bp}: \\
\mathrm{rps} 19\end{array}$} & 34 bp & $1723 \mathrm{bp}$ & $74 \mathrm{bp}$ & $4301 \mathrm{bp}$ & \multirow[t]{2}{*}{1396 bp } & & \multirow[t]{2}{*}{$\operatorname{trnH}$} \\
\hline & & 9 $\quad r p l 2$ & $\operatorname{trnN}$ & $n d h F$ & $y c f 1$ & & $r p l 2$ & \\
\hline \multirow[t]{3}{*}{ V. japonicum } & LSC & IRb & 26,516 & SSC & 18,523 & IRa & 26,516 & LSC \\
\hline & $245 \mathrm{bp}$ & $34 \mathrm{bp}$ & $1723 \mathrm{bp}$ & $62 \mathrm{bp}$ & $4301 \mathrm{bp}$ & \multirow[t]{2}{*}{$1396 \mathrm{bp}$} & & $\operatorname{trnH}$ \\
\hline & rps19 & $r p l 2$ & $\operatorname{trnN}$ & $n d h F$ & $y c f 1$ & & $r p l 2$ & \\
\hline \multirow[t]{3}{*}{ V. erosum } & LSC & $\mathrm{IRb}$ & 26,517 & SSC & 18,530 & IRa & 26,517 & LSC \\
\hline & \multirow{2}{*}{\multicolumn{2}{|c|}{$\begin{array}{c}245 \mathrm{bp} 34 \mathrm{bp} \\
\text { rps19 } \quad r p l 2\end{array}$}} & 1372 bp & & \multirow{2}{*}{\multicolumn{2}{|c|}{$\begin{array}{l}4618 \text { bp } 1044 \\
y c f 1\end{array}$}} & $80 \mathrm{bp}$, & $\operatorname{trn} H$ \\
\hline & & & $\operatorname{trn} N$ & $n d h F$ & & & $r p l 2$ & \\
\hline \multirow[t]{3}{*}{ V. brachybotryum } & LSC & $\mathrm{IRb}$ & 26,133 & SSC & 18,615 & IRa & 26,133 & LSC \\
\hline & $97 \mathrm{bp}$ & $107 \mathrm{bp}$ & $1366 \mathrm{bp}$ & $17 \mathrm{bp}$ & \multirow{3}{*}{$\begin{array}{c}4733 \mathrm{bp} \\
y c f 1\end{array}$} & \multirow[t]{2}{*}{$1048 \mathrm{bp}$} & $330 \mathrm{bp}$ & \\
\hline & rps19 & $r p l 2$ & $\operatorname{trnN}$ & $n d h F$ & & & $r p l 2$ & \\
\hline T. omeiensis & LSC & $\mathrm{IRb}$ & 26,147 & SSC & & IRa & 26,147 & LSC \\
\hline
\end{tabular}

Figure 3. Comparison of IR/SC boundary of chloroplast genomes in seven species.

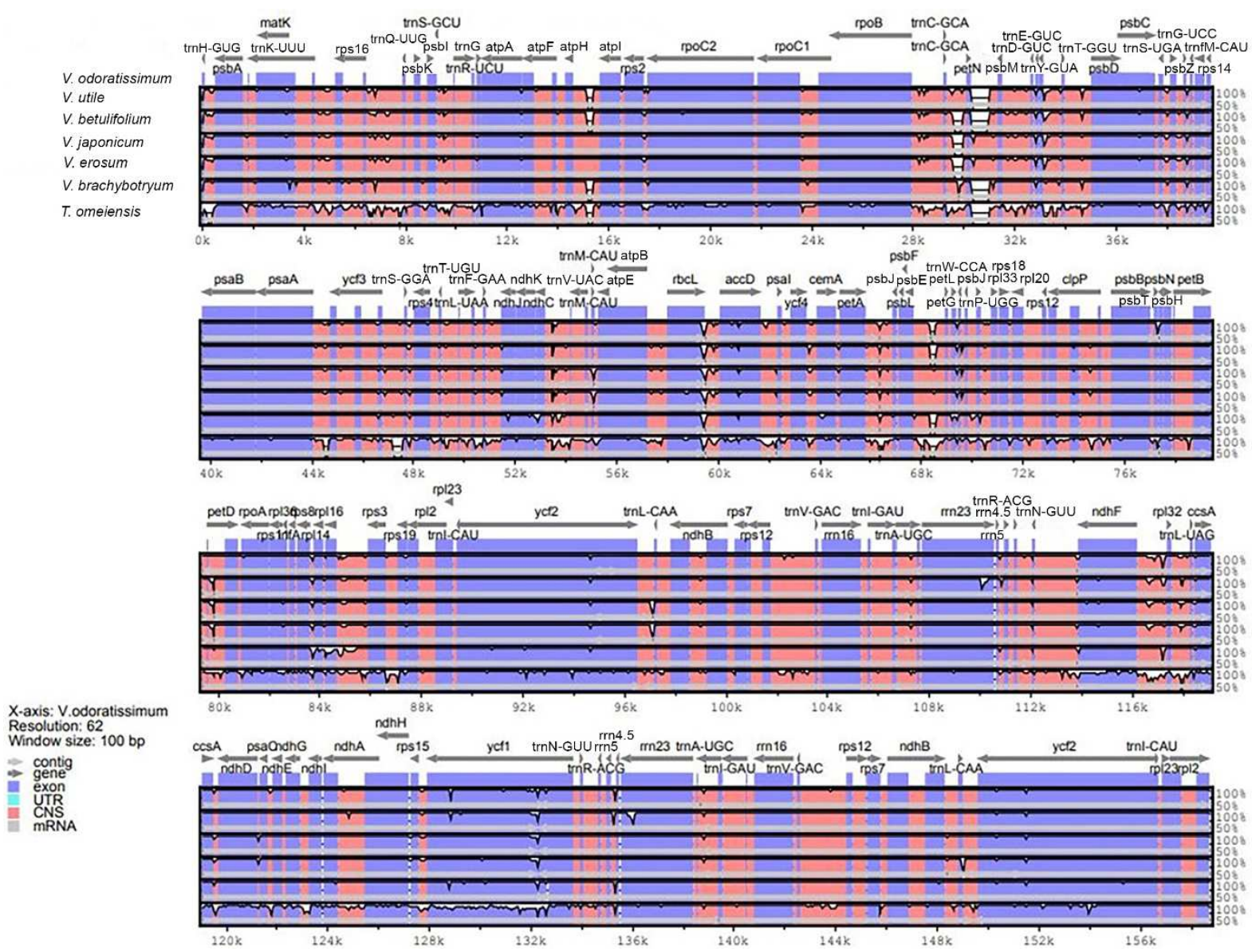

Figure 4. The alignment of the seven complete chloroplast genomes. 


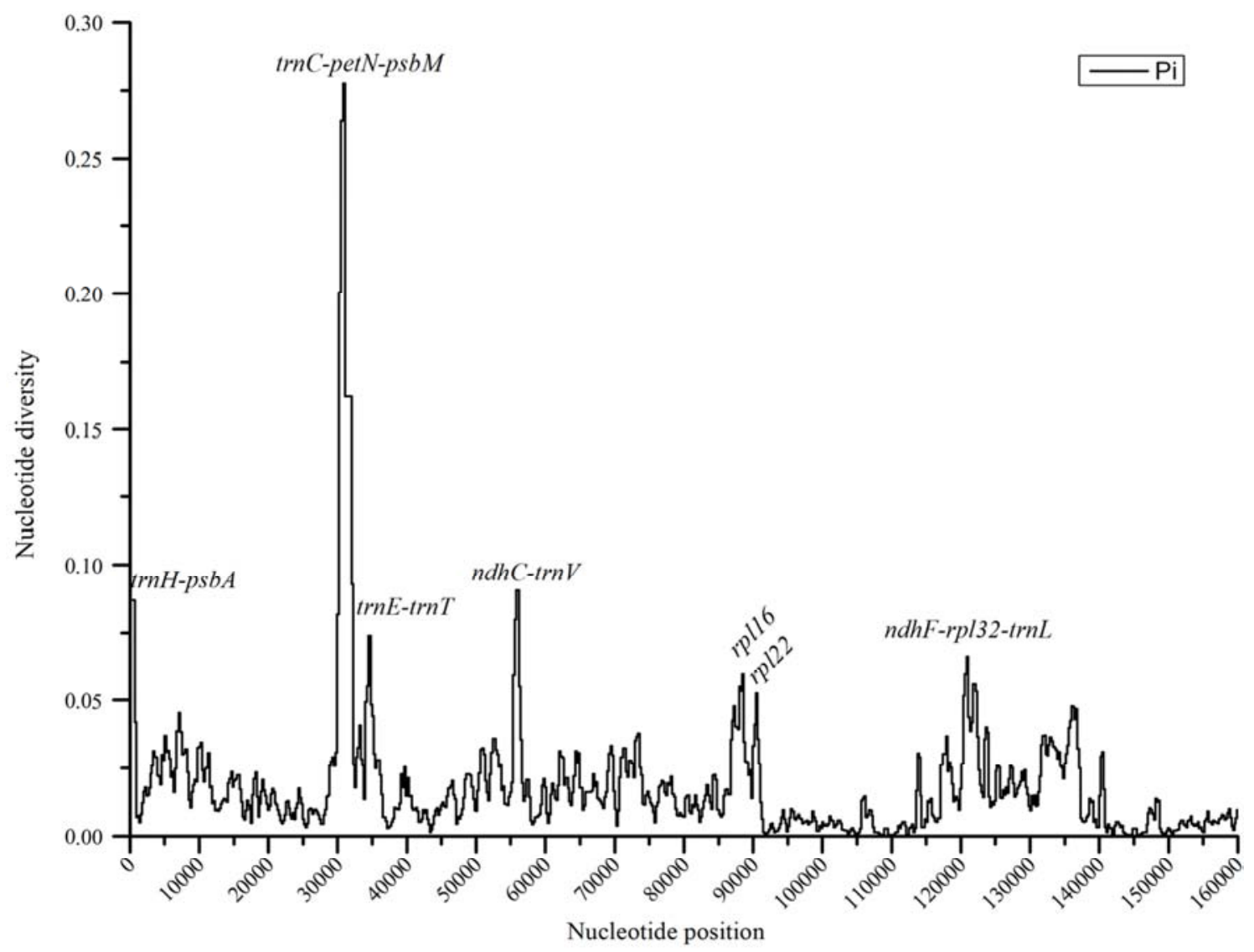

Figure 5. Nucleotide variability (Pi) values of the seven chloroplast genomes using DnaSP analysis.

\subsubsection{Phylogenetic Analysis}

To identify the phylogenetic relationship between $V$. odoratissimum and other species within the Viburnum genus, Randomized Axelerated maximum likelihood (RAxML) method was performed based on plastid genomes of 10 species, with T. omeiensis and S. nigra used as outgroups. The resulting phylogenetic tree is shown in Figure 6. The eight Viburnum species are divided into three clades. $V$. odoratissimum and $V$. brachybotryum form a clade Solenotinus. V. betulifolium, V. japonicum, $V$. erosum and $V$. dilatatum classify in the clade Succotinus. Solenotius along with Succotinus are members of a large clade Pluriviburnum. $V$. carcephalum and V. utile belong to the clade Euviburnum.

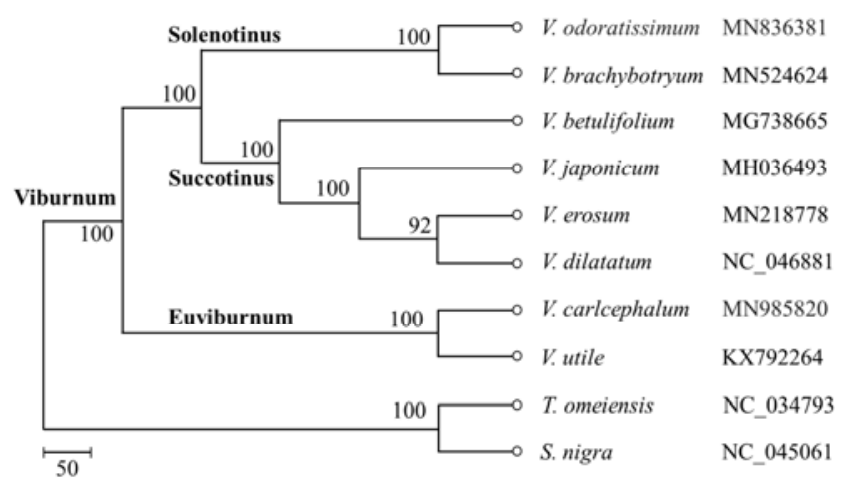

Figure 6. Phylogenetic reconstruction based on 10 complete chloroplast genomes

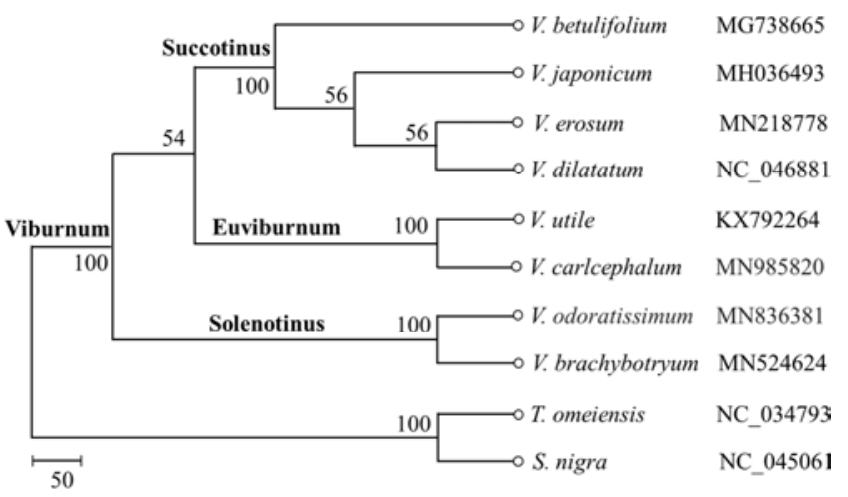

Figure 7. Phylogenetic reconstruction based on the combination of trnHpsbA, trnC-petN, and ndhC-trnV regions from eight Viburnum species and two outgroups.

DNA barcodes have proven to possess an expanding range of application in taxonomical studies. In plants, most DNA barcoding regions are located in the chloroplast genome and a few are in the ITS regions of nuclear ribosomal genes [30]. Several chloroplast-derived barcodes were identified and recommended for species discrimination, including coding regions (matK, rpoB, ycfl, accD, rbcL, and $n d h J)$ and noncoding regions $(t r n H-p s b A, a p F-a t p H)$ [31-33]. However, no single DNA region is able to be a promising candidate for all plants. As a result, the combination of a DNA barcode sequence of more than one barcode should be typically used to provide more accurate species identification [34] In the Viburnum genus, a single barcode trnK, a combination of 
$r b c L, m a t K$ and $t r n H-p s b A$, and the ITS region [1, 13] were used to discriminate Viburnum species, but these regions still remain some unresolved issues and conflicting relationships. In this study, a combination of three hotspot regions (trnHpsbA, trnC-pet $N$, and $n d h C-t r n V)$ that exhibit high divergence by a sliding window analysis in the Viburnum species were used to construct a phylogenetic tree of above 10 species. The result (Figure 7) shows a similar pattern with the data based on the complete chloroplast genomes, revealing a high discriminatory power of this combination that could be a promising genetic marker for phylogenetic relationship studies.

\section{Conclusion}

In this study, using PacBio RS II system sequencing technology, we report the complete chloroplast genome of $V$. odoratissimum. Compare with the other Adoxaceae genomes, the size of $V$. Odoratissimum plastid genome and coding regions is largest, but the gene content and organization are highly similar, except for the abundance of pseudogenes in $V$. brachybotryum. The divergence hotspot region analysis provides a combination of barcodes (trnH-psbA, trnC-pet N, and $n d h(-t r n V)$ that can be used as a potential genetic marker for discrimination of Viburnum species and phylogenetic tree reconstruction.

\section{Acknowledgements}

This study was supported by the Research Project funded by the Seoul National University of Science and Technology.

\section{References}

[1] Donoghue, M. J., Baldwin, B. G., Li, J. and Winkworth, R. C. (2004) Viburnum Phylogeny Based on Chloroplast TrnK Intron and Nuclear Ribosomal ITS DNA Sequences. Systematic Botany, 29, 188-198. https://doi.org/10.1600/036364404772974095.

[2] Killip, E. P. and Smith, A. C. (1929) The Genus Viburnum in Northwestern South America. Bulletin of the Torrey Botanical Club, 56, 265. https://doi.org/10.2307/2480649.

[3] The Angiosperm Phylogeny Group. (2016) An Update of the Angiosperm Phylogeny Group Classification for the Orders and Families of Flowering Plants: APG IV. Botanical Journal of the Linnean Society, 181, 1-20. https://doi.org/10.1111/boj.12385.

[4] Ge, Y.-C., Zhang, H.-J., Lei, J.-X. and Wang, K.-W. (2018) Chemical Constituents of Viburnum Odoratissimum and Their Cytotoxic Activities. Chemistry of Natural Compounds, 54, 600-602. https://doi.org/10.1007/s10600-018-2422-z.

[5] Velioglu, Y. S., Ekici, L. and Poyrazoglu, E. S. (2006) Phenolic Composition of European Cranberrybush (Viburnum Opulus L.) Berries and Astringency Removal of Its Commercial Juice. International Journal of Food Science \& Technology, 41, 1011-1015. https://doi.org/10.1111/j.13652621.2006.01142.x.
[6] Wang, L.-Q., Chen, Y.-G., Xu, J.-J., Liu, Y., Li, X.-M. and Zhao, Y. (2008) Compounds from Viburnum Species and Their Biological Activities. Chemistry \& Biodiversity, 5, 1879-1899. https://doi.org/10.1002/cbdv.200890175.

[7] Bock, K., Jensen, S. R., Nielsen, B. J. and Norn, V. (1978) Iridoid Allosides from Viburnum Opulus. Phytochemistry, 17, 753-757. https://doi.org/10.1016/S0031-9422(00)94220-1.

[8] Nguyen, T. T., Truong, B. N., Doan Thi Mai, H., Litaudon, M., Nguyen, V. H., Do Thi, T., Chau, V. M. and Pham, V. C. (2017) Cytotoxic Dammarane-Type Triterpenoids from the Leaves of Viburnum Sambucinum. Bioorganic \& Medicinal Chemistry Letters, 27, 1665-1669. https://doi.org/10.1016/j.bmcl.2017.03.014.

[9] Sagdic, O., Aksoy, A. and Ozkan, G. (2006) Evaluation of the Antibacterial and Antioxidant Potentials of Cranberry (Gilaburu, Viburnum Opulus L.) Fruit Extract. Acta Alimentaria, Akadémiai Kiadó, 35, 487-492. https://doi.org/10.1556/AAlim.35.2006.4.12.

[10] Wang, L.-X., Fang, Y.-D., Zhang, R.-H., Ren, F.-C., Zhang, X.-J., Wang, F. and Xiao, W.-L. (2018) Hispanane-Type Diterpenoid and Secoiridoid Glucosides from Viburnum Cylindricum. Chemistry \& Biodiversity, 15, e1700418. https://doi.org/10.1002/cbdv.201700418.

[11] Donoghue, M. J. (1983) A Preliminary Analysis of Phylogenetic Relationships in Viburnum (Caprifoliaceae s.1.). Systematic Botany, American Society of Plant Taxonomists, 8 , 45-58. https://doi.org/10.2307/2418562.

[12] Winkworth, R. C. and Donoghue, M. J. (2004) Viburnum Phylogeny: Evidence from the Duplicated Nuclear Gene GBSSI. Molecular Phylogenetics and Evolution, 33, 109-126. https://doi.org/10.1016/j.ympev.2004.05.006.

[13] Choi, Y. G., Youm, J. W., Lim, C. E. and Oh, S. H. (2018) Phylogenetic Analysis of Viburnum (Adoxaceae) in Korea Using DNA Sequences. Korean Journal of Plant Taxonomy, 48, 206-217. https://doi.org/10.11110/kjpt.2018.48.3.206.

[14] Clement, W. L. and Donoghue, M. J. (2012) Barcoding Success as a Function of Phylogenetic Relatedness in Viburnum, a Clade of Woody Angiosperms. BMC Evolutionary Biology, 12, 73. https://doi.org/10.1186/14712148-12-73.

[15] Soltis, D., Soltis, P., Endress, P., Chase, M. W., Manchester, S., Judd, W., Majure, L. and Mavrodiev, E. (2018) Phylogeny and Evolution of the Angiosperms: Revised and Updated Edition. University of Chicago Press.

[16] Huo, Y., Gao, L., Liu, B., Yang, Y., Kong, S., Sun, Y., Yang, Y. and $\mathrm{Wu}, \mathrm{X}$. (2019) Complete Chloroplast Genome Sequences of Four Allium Species: Comparative and Phylogenetic Analyses. Scientific Reports, 9, 1-14. https://doi.org/10.1038/s41598-019-48708-x.

[17] Sahu, S. K., Thangaraj, M. and Kathiresan, K. (2012) DNA Extraction Protocol for Plants with High Levels of Secondary Metabolites and Polysaccharides without Using Liquid Nitrogen and Phenol. ISRN Molecular Biology, 2012. https://doi.org/10.5402/2012/205049.

[18] Li, H. and Durbin, R. (2009) Fast and Accurate Short Read Alignment with Burrows-Wheeler Transform. $\begin{array}{lll}\text { Bioinformatics, } & \text { 25, }\end{array}$ https://doi.org/10.1093/bioinformatics/btp324. 
[19] Koren, S., Walenz, B. P., Berlin, K., Miller, J. R., Bergman, N. H. and Phillippy, A. M. (2017) Canu: Scalable and Accurate Long-Read Assembly via Adaptive k-Mer Weighting and Repeat Separation. Genome Research, 27, 722-736. https://doi.org/10.1101/gr.215087.116.

[20] Tillich, M., Lehwark, P., Pellizzer, T., Ulbricht-Jones, E. S., Fischer, A., Bock, R. and Greiner, S. (2017) GeSeq Versatile and Accurate Annotation of Organelle Genomes. Nucleic Acids Research, 45, W6-W11. https://doi.org/10.1093/nar/gkx391.

[21] Greiner, S., Lehwark, P. and Bock, R. (2019) OrganellarGenomeDRAW (OGDRAW) Version 1.3.1: Expanded Toolkit for the Graphical Visualization of Organellar Genomes. Nucleic Acids Research, 47, W59-W64. https://doi.org/10.1093/nar/gkz238.

[22] Benson, G. (1999) Tandem Repeats Finder: A Program to Analyze DNA Sequences. Nucleic Acids Research, 27, 573580. https://doi.org/10.1093/nar/27.2.573.

[23] Beier, S., Thiel, T., Münch, T., Scholz, U. and Mascher, M. (2017) MISA-Web: A Web Server for Microsatellite Prediction. Bioinformatics, Oxford Academic, 33, 2583-2585. https://doi.org/10.1093/bioinformatics/btx198.

[24] Frazer, K. A., Pachter, L., Poliakov, A., Rubin, E. M. and Dubchak, I. (2004) VISTA: Computational Tools for Comparative Genomics. Nucleic Acids Research, 32, W273W279. https://doi.org/10.1093/nar/gkh458.

[25] Thompson, J. D., Gibson, T. J., Plewniak, F., Jeanmougin, F. and Higgins, D. G. (1997) The CLUSTAL_X Windows Interface: Flexible Strategies for Multiple Sequence Alignment Aided by Quality Analysis Tools. Nucleic Acids Research, 25, 4876-4882.

[26] Rozas, J., Ferrer-Mata, A., Sánchez-DelBarrio, J. C., GuiraoRico, S., Librado, P., Ramos-Onsins, S. E. and SánchezGracia, A. (2017) DnaSP 6: DNA Sequence Polymorphism Analysis of Large Data Sets. Molecular Biology and Evolution, 34, 3299-3302. https://doi.org/10.1093/molbev/msx248.

[27] Li, W., Yang, W. and Wang, X.-J. (2013) Pseudogenes:
Pseudo or Real Functional Elements? Journal of Genetics and Genomics, 40, 171-177. https://doi.org/10.1016/j.jgg.2013.03.003.

[28] Li, X., Tan, W., Sun, J., Du, J., Zheng, C., Tian, X., Zheng, M., Xiang, B. and Wang, Y. (2019) Comparison of Four Complete Chloroplast Genomes of Medicinal and Ornamental Meconopsis Species: Genome Organization and Species Discrimination. Scientific Reports, 9. https://doi.org/10.1038/s41598-019-47008-8.

[29] Powell, W., Morgante, M., McDevitt, R., Vendramin, G. G. and Rafalski, J. A. (1995) Polymorphic Simple Sequence Repeat Regions in Chloroplast Genomes: Applications to the Population Genetics of Pines. Proceedings of the National Academy of Sciences, 92, 7759-7763. https://doi.org/10.1073/pnas.92.17.7759.

[30] Chen, S., Yao, H., Han, J., Liu, C., Song, J., Shi, L., Zhu, Y., Ma, X., Gao, T., Pang, X., Luo, K., Li, Y., Li, X., Jia, X., Lin, Y. and Leon, C. (2010) Validation of the ITS2 Region as a Novel DNA Barcode for Identifying Medicinal Plant Species. PLOS ONE, Public Library of Science, 5, e8613. https://doi.org/10.1371/journal.pone.0008613.

[31] Ford, C. S., Ayres, K. L., Toomey, N., Haider, N., Van Alphen Stahl, J., Kelly, L. J., Wikström, N., Hollingsworth, P. M., Duff, R. J., Hoot, S. B., Cowan, R. S., Chase, M. W. and Wilkinson, M. J. (2009) Selection of Candidate Coding DNA Barcoding Regions for Use on Land Plants. Botanical Journal of the Linnean Society, Oxford Academic, 159, 1-11. https://doi.org/10.1111/j.1095-8339.2008.00938.x.

[32] Johnson, M. and Trott, T. (2017) DNA Barcoding of Quercus Falcata, Quercus Palustris, Quercus Rubra, and Their Hybrids Using RbcL, MatK, and Ycfl. 26.

[33] Kress, W. J. and Erickson, D. L. (2007) A Two-Locus Global DNA Barcode for Land Plants: The Coding RbcL Gene Complements the Non-Coding TrnH-PsbA Spacer Region. PLOS ONE, Public Library of Science, 2, e508. https://doi.org/10.1371/journal.pone.0000508.

[34] Shneyer, V. S. and Rodionov, A. V. (2019) Plant DNA Barcodes. Biology Bulletin Reviews, 9, 295-300. https://doi.org/10.1134/S207908641904008X. 